\title{
Biografia bez pudru
}

Zmarła tragicznie w katastrofie lotniczej pod Smoleńskiem Anna Walentynowicz stanowi jedną z ikon antykomunistycznej opozycji w PRL. To przecież w jej obronie w sierpniu 1980 roku grupa działaczy i sympatyków Wolnych Związków Zawodowych Wybrzeża zorganizowała w Stoczni Gdańskiej im. Lenina strajk, który zaowocował powstaniem Solidarności i zachwiał monopolistyczną władzą PZPR. Jej postać od dawna intryguje dziennikarzy, filmowców, historyków i pisarzy. Jeden z pierwszych dużych artykułów na jej temat opatrzono znamiennym tytułem Anna Proletariuszka ${ }^{1}$. Andrzej Wajda wykorzystał jej historię, kreując postać jednej z głównych bohaterek znakomitego Człowieka z żelaza (1981), a ćwierć wieku później zainspirowała ona znanego niemieckiego reżysera Volkera Schlöndorffa do nakręcenia głośnego filmu Strajk. Bohaterka z Gdańska (2007).

Paradoksalnie na biografię, która kompleksowo, a zarazem obiektywnie ukazuje zawiłe losy słynnej suwnicowej przyszło nam czekać aż do 2020 roku. Dotychczasowe publikacje na jej temat były bowiem albo jednostronne, to znaczy oparte na wypowiedziach samej Walentynowicz i niekonfrontowane z innymi źródłami², albo pisane w sposób mało obiektywny, by nie powiedzieć - pod z góry założoną tezę ${ }^{3}$, albo przyczynkowe, to znaczy skupiające się wyłącznie na wybranych fragmentach jej życiorysu4.

1. B. Holub, Anna Proletariuszka, "Czas" 1980, nr 52.

2. T. Jastrun, Życie Anny Walentynowicz, wyd. 2, Warszawa 2011; H. Krall, Ludzie może i nie sa tacy źli..., https://fpalma.pl/wp-content/uploads/2018/02/Warsztaty_reporterskie_B0_LEKTURY.pdf (dostęp: 25.06.2010); J. Surdykowski, Kobieta z marmuru, [w:] eadem, Notatki gdańskie, Kraków 1984, s. 83-88; A. Walentynowicz, A. Baszanowska, Cień przyszłości, Gdańsk 1993.

3. S. Cenckiewicz, Anna Solidarność. Życie i działalność Anny Walentynowicz na tle epoki (1929-2010), Poznań 2010; S. Cenckiewicz, A. Chmielecki, Anna Walentynowicz 1929-2010, Warszawa 2017.

4. I. Hałagida, Nieznane dzieciństwo Anny Walentynowicz, "Pamięć.pl" 2016, nr 7/8. Biogramy Walentynowicz można też znaleźć w publikacjach Piotra Adamowicza, Arkadiusza Kazańskiego, Shany Penn i Jarosława Szarka. Nie wnoszą one jednak nowych ustaleń badawczych, lecz podsumowują dotychczasowy stan wiedzy, zob.: P. Adamowicz, Anna Walentynowicz, [w:] Słownik dysydentów. Czołowe postacie ruchów opozycyjnych $w$ krajach komunistycznych w latach 1956-1989, t. 1, red. J. Kochanowski, koordynacja A. Daniel, Z. Gluza, Warszawa 2007, s. 710-713; A. Kazański, Anna Walentynowicz (1929-2010), Warszawa 2015; S. Penn, Anna Walentynowicz i sierpniowe strajki 1980

\section{PIOTR BRZEZINSKI}

Recenzja książki: Dorota Karaś, Marek Sterlingow, Walentynowicz. Anna szuka raju, Kraków: Znak, 2020, 510 ss. 
Autorzy książki Walentynowicz. Anna szuka raju to dwoje trójmiejskich dziennikarzy związanych z "Gazetą Wyborczą". Dorota Karaś wydała niedawno biografię Zbigniewa Cybulskiego50, a Marek Sterlingow to między innymi współautor popularnonaukowej publikacji dotyczącej powstania Solidarności ${ }^{6}$. Ich najnowsza książka łączy w sobie dziennikarskie zacięcie z gruntowną znajomością tematu i dobrym warsztatem pisarskim, co pozytywnie wyróżnia ją na tle innych publikacji dziennikarzy sięgających w ostatnich latach po kwestie historyczne. Jak sami twierdzą, praca nad nią zajęła im trzy lata ${ }^{7}$.

Książka ma charakter popularnonaukowy, a przypisy w tekście ograniczają się do niezbędnego minimum, to znaczy do cytatów z dokumentów i niektórych szczególnie ważnych informacji zapożyczonych $\mathrm{z}$ literatury przedmiotu. W niczym nie deprecjonuje to jednak recenzowanej publikacji, którą uważam za przykład popularyzacji historii na wysokim poziomie.

W pełni też potwierdza się tu pogląd Normana Daviesa mówiący, że książek historycznych nie powinno się dzielić na naukowe i popularnonaukowe, gdyż historia jest napisana albo źle, albo dobrze.

Praca opiera się na bogatym materiale źródłowym, obejmującym zarówno obfitą literaturę przedmiotu, dokumentację archiwalną zgromadzoną w sześciu archiwach, jak i wywiady przeprowadzone przez autorów z 46 rozmówcami. W bibliografii autorzy powołują się na 65 książek, 168 artykułów, 12 archiwalnych materiałów dźwiękowych i 24 nagrania filmowe. Przeprowadzona przez nich kwerenda objęła: Archiwum Historii Mówionej Ośrodka „Karta”, Archiwum Instytutu Pamięci Narodowej,
Archiwum Państwowe w Gdańsku, Archiwum Parafii Najświętszego Serca Jezusowego w Gdańsku-Wrzeszczu, Archiwum Służby Bezpieczeństwa Ukrainy i Archiwum Zakładowe Stoczni Gdańskiej.

Poszczególne fragmenty książki były konsultowane $\mathrm{z}$ grupą profesjonalnych historyków, a całość publikacji zaopiniował przed drukiem Jan Olaszek z Instytutu Pamięci Narodowej. Na szczególną uwagę zasługuje to, że autorzy rozmawiali nie tylko z byłymi współpracownikami Walentynowicz, jej krewnymi i znajomymi, lecz także $\mathrm{z}$ inwigilującymi ją przed laty funkcjonariuszami SB i agentami bezpieki. Odbyli też rozmowy z autorami wcześniejszych publikacji na jej temat (Anną Baszanowską, Sławomirem Cenckiewiczem, Mieczysławem Jastrunem i Hanną Krall), a także z niemiecką dokumentalistką i autorką filmu o Walentynowicz, Sylke René Meyer. Udało im się również dotrzeć do wielogodzinnego nagrania niepublikowanego nigdy wywiadu, który w latach osiemdziesiątych przeprowadziła z Anną Walentynowicz znana dziennikarka Janina Jankowska. Jak podkreślają autorzy, szczególnie cenne okazały się jednak relacje jej syna Januszå.

Dorota Karaś i Marek Sterlingow już na pierwszych stronach książki opisują swój niedawny wyjazd na Ukrainę i spotkanie z żyjącymi tam krewnymi Anny Walentynowicz. Wątek ten jest kluczowy dla zrozumienia skomplikowanych losów bohaterki recenzowanej publikacji, toteż warto poświęcić mu nieco więcej uwagi. Okazuje się, że przytaczana we wszystkich wcześniejszych biografiach oficjalna wersja jej życiorysu została po prostu sfałszowana. Kilka lat temu jako pierwszy w polskiej historiografii na kwestię tę zwrócił uwagę Igor Hałagida.

roku, [w:] eadem, Sekret „Solidarności”. Kobiety, które pokonały komunizm w Polsce, tłum. M. Antosiewicz, Warszawa 2014, s. 57-97; J. Szarek, Sztandar Polskiego Sierpnia (Anna Walentynowicz), [w:] M. Korkuć, F. Musiał, J. Szarek, Po dwóch stronach barykady PRL. Towarzysze, zdrajcy, bohaterowie, niezłomni, Kraków 2007, s. 296-306.

5. D. Karaś, Cybulski. Podwójne salto, Kraków 2016.

6. M. Sterlingow [i in.], Narodziny Solidarności. Kroniki sierpniowe, red. M. Drzewicki, M. Ręczmin, Gdańsk 2010.

7. D. Szreter, Anna Walentynowicz wywołuje skrajne emocje. Jej biografia nie jest czarno-białą historia - mówią autorzy "Walentynowicz. Anna szuka raju”, "Dziennik Bałtycki”, 15.03.2020.

8. Ibidem. 
Mimo to oficjalny biogram Walentynowicz zamieszczony w internetowej Encyklopedii Solidarności wciąż brzmi następująco: „We IX 1939 straciła rodziców, jedynego brata Sowieci wywieźli na Wschód, przygarnięta przez sąsiadów, w 1941 przedostała $\mathrm{z}$ nimi się pod Warszawę ${ }^{\prime \prime}$. Sama Walentynowicz twierdziła, że przyszła na świat w Równem na Wołyniu w polskiej katolickiej rodzinie. Jej ojciec Jan miał zginąć we wrześniu 1939 roku, matka Aleksandra umrzeć wkrótce potem, starszy brat Andrzej, jako polski patriota, miał zaś zostać zesłany przez Sowietów na Syberię.

W rzeczywistości Anna Lubczyk (bo tak brzmiało jej panieńskie nazwisko) urodziła się w 1929 roku we wsi Sienne (obecnie Sadowe), która leży około trzydziestu kilometrów od Równego. Jej rodzicami byli Nazar i Pryśka Lubczykowie. Oboje byli Ukraińcami wyznania protestanckiego (tak zwanymi sztundystami), a sama Anna - jak ustalili autorzy książki na podstawie ksiąg parafialnych kościoła Najświętszego Serca Jezusowego w Gdańsku-Wrzeszczu - przyjęła chrzest dopiero wiosną 1964 roku, czyli tuż przed ślubem z Kazimierzem Walentynowiczem (s. 130). Z zachowanych dokumentów i relacji jej ukraińskich krewnych wynika, że Anna faktycznie miała starszego (przyrodniego) brata, lecz nosił on imię Iwan, a nie Andrzej. Miała też dalsze rodzeństwo: Olhę, Petra, Katerynę, Nadię (zmarła w dzieciństwie) i Wasyla. W 1952 roku na świat przyszła jej najmłodsza, tym razem przyrodnia siostra Anna, z którą poznała się dopiero w latach dziewięćdziesiątych (s. 14, 437-444).

Dociekliwi autorzy dotarli też do dokumentów Służby Bezpieczeństwa Ukrainy, z których wynika, że starszy przyrodni brat Anny Iwan Suszczuk rzeczywiście został wywieziony na Syberię. Powodem wywózki nie był jednak jego polski patriotyzm, lecz przynależność do Ukraińskiej Powstańczej Armii. Wstąpił do niej ochotniczo latem 1943 roku. 0 tym, że w tej zbrodniczej organizacji (odpowiedzialnej za śmierć od 100 tysięcy do 185 tysięcy Polaków z Wołynia i Małopolski Wschodniej ${ }^{10}$ ) nie znalazł się przypadkowo, najlepiej świadczy fakt, że zajmował się w niej szkoleniem wojskowym dwudziestoosobowego oddziału złożonego z mieszkających w okolicy młodych mężczyzn. Aresztowany w 1944 roku przez żołnierzy Armii Czerwonej, szczegółowo opisał swoją działalność podczas przesłuchania. Za odmowę wstąpienia do sowieckiego wojska został skazany na 15 lat łagru i zesłany do kopalni węgla w Workucie w odległej Republice Komi (s. 25-29). Przeżył łagier i po wielu latach wrócił w rodzinne strony (s. 438).

Wbrew opowieściom Anny Walentynowicz jej rodzice nie zginęli we wrześniu 1939 roku. Matka zmarła dwa lata wcześniej, a ojciec niebawem ożenił się ponownie, przeżył II wojnę światową, a nawet dożył do 1995 roku. Trudna sytuacja finansowa zmusiła go w 1941 roku do oddania dwunastoletniej Anny na służbę do polskich sąsiadów, zamożnej rodziny Teleśnickich (s. 23). W 1943 roku Teleśniccy zabrali cały swój ruchomy dobytek i wyjechali do Polski, w porę uciekając przed mordującymi Polaków banderowcami. Zabrali ze sobą Annę, która od tego momentu na ponad pół wieku straciła jakikolwiek kontakt z mieszkającą na Wołyniu rodziną. Bardzo prawdopodobne, że faktycznie uwierzyła w to, iż wszyscy jej bliscy zginęli w wojennej pożodze. Po wkroczeniu na Wołyń Sowietów Nazar Lubczyk został zmobilizowany do Armii Czerwonej i wziął udział w walkach z wycofującymi się na zachód Niemcami. W dowód wojennej odwagi otrzymał sowiecki Order Sławy III klasy. Po wojnie został listonoszem (s. 29-30).

Dopiero w latach dziewięćdziesiątych poszukiwania zaginionej siostry rozpoczęła najmłodsza z rodzeństwa Lubczyków, Anna Kurbanowa. Losy obu sióstr splotły się zresztą nieco wcześniej.

9. M. Łątkowska, A. Borowski, Anna Walentynowicz [hasło], Encyklopedia Solidarności, http://www.encysol.pl/wiki/Anna_ Walentynowicz (dostęp: 5.06.2020).

10. L. Kulińska, C. Partacz, Ludobójstwo niepotępione. Zbrodnie OUN-UPA na Polakach 1939-1945, Warszawa 2015 , s. 118. 
Jak piszą autorzy książki: „W latach osiemdziesiątych do dyrektora szkoły w Sadowem zadzwoniło KGB. Radzieckie służby zainteresowały się polską opozycjonistką, bo jako miejsce urodzenia podawała w dokumentach ZSRR. Nauczyciel potwierdził, że we wsi mieszka Anna Lubczyk. Tyle że chodziło mu o młodszą córkę Nazara. KGB uznało sprawę za wyjaśnioną. Zwłaszcza że Lubczyk w żadnych dokumentach nie przyznawał się do córki w Polsce" (s. 441). To właśnie Anna Kurbanowa nadała w lokalnym radiu apel informujący o tym, że poszukuje zaginionej w 1943 roku siostry, która wyjechała do Polski. Audycję usłyszał miejscowy historyk Jefrem Hasaj, który skojarzył fakt, że znana polska opozycjonistka Anna Walentynowicz pochodzi z Wołynia, a jej panieńskie nazwisko to Lubczyk. Napisał więc do niej list i w ten sposób nawiązał kontakt.

Pod koniec 1996 roku Anna Walentynowicz przyjechała w rodzinne strony i spotkała się z krewnymi. Na pamiątkę tamtego wzruszającego spotkania podarowała siostrom egzemplarz swojej biografii zatytułowanej Cień przyszłości. Na stronie tytułowej wykaligrafowała dedykację: „Swoją biografię przekazuję całej swojej Rodzinie Nazarowych. Jest to dokument, gdzie byłam i co robiłam w czasie naszej 53-letniej rozłąki". Pod dedykacją podpisała się: "Anna Lubczyk - Walentynowicz Nazarowa”, i opatrzyła ją datą: 3 grudnia 1996 r. (s. 9).

Po powrocie do Polski opowiedziała o wszystkim Henryce Krzywonos, wyraźnie wstydząc się przynależności starszego brata do UPA. Poprosiła ją jednak o dyskrecję (s. 443). Od tej pory spotykała się ze swoimi ukraińskimi krewnymi niemal co roku. Co ciekawe, nigdy nie opowiedziała prawdziwej historii swojej rodziny synowi Januszowi. Nie poznali jej też ani przygotowująca drugie wydanie Cienia przyszłości Anna Baszanowska, ani piszący na jej temat habilitację Sławomir Cenckiewicz (s. 444, 466). Annie Kurbanowej powiedziała natomiast: "Jak umrę w Ukrainie, to mnie tu pochowajcie. A jeśli w Polsce, to na pogrzeb nie przyjeżdżajcie" (s. 444). Czyżby wstydziła się swoich ukraińskich korzeni?

Nigdy się już nie dowiemy, dlaczego Anna Walentynowicz tak konsekwentnie ukrywała swoje pochodzenie. W jednym z wywiadów Marek Sterlingow stwierdzit, że "najwyraźniej - i mówię to z pewnym wstydem - odczytała nastroje społeczne tak, że nawet będąc bohaterką polskiej wolności, czuła, że nie powinna o tym mówić. To trochę smutne"11. Czy aby na pewno? Rozumiem, że w okresie PRL mogła obawiać się, że komunistyczna bezpieka będzie chciała zagrać tą kartą i przedstawić ją jako ukrywającą swoje prawdziwe oblicze siostrę „ukraińskiego rezuna". Szczerze wątpię jednak w to, że po 1989 roku robiono by jej z tego powodu jakiekolwiek wyrzuty. Podejrzewam, że byłoby wręcz odwrotnie, a jej postać stałaby się dla niektórych środowisk ważnym symbolem i swego rodzaju pomostem łączącym oba narody. Wielka szkoda, że osoba, która przez lata walczyła o wolność słowa i elementarną prawdę (choćby na temat agenturalnego uwikłania Lecha Wałęsy w latach siedemdziesiątych), nie znalazła w sobie dość odwagi, aby powiedzieć prawdę o własnym pochodzeniu.

$\mathrm{Z}$ kart recenzowanej książki wyłania się obdarzona temperamentem $i$ apodyktycznym charakterem kobieta $\mathrm{z}$ krwi i kości. Jej życie nie było łatwe: dojmująca bieda i wieloletnia rozłąka z rodziną, ciężka służba u Teleśnickich, wyniszczająca praca w stoczni, zatargi z kierownictwem zakładu, bolesny zawód miłosny, samotne macierzyństwo, wreszcie przedwczesna śmierć ukochanego mężczyzny i wieloletnia inwigilacja przez komunistyczną bezpiekę. Z drugiej strony autorzy książki nie przemilczają faktu, że Anna Walentynowicz przez lata z zapałem budowała Polskę Ludową i wierzyła kolejnym komunistycznym przywódcom: najpierw Bolesławowi Bierutowi, potem Władysławowi Gomułce, a następnie Edwardowi Gierkowi, którego sama zresztą radośnie witała w Gdańsku w styczniu 1971 roku. Była też ideowo zaangażowaną aktywist-

11. D. Szreter, Anna Walentynowicz wywołuje skrajne emocje... 
ką reżimowego Związku Młodzieży Polskiej i Ligi Kobiet oraz wykorzystywaną propagandowo przodownicą pracy. Co więcej, w latach czterdziestych o mały włos nie zatrudniła się jako sprzątaczka w Urzędzie Bezpieczeństwa (s. 54-55), a w latach sześćdziesiątych planowała zapisać się do ORM0 (s. 150).

Trzeba też uczciwie przyznać, że władzy komunistycznej zawdzięczała niemało. Jako osoba samotna i słabo wykształcona (zaledwie cztery klasy szkoły powszechnej) dostała bardzo odpowiedzialną pracę w jednym z głównych zakładów przemysłowych kraju. Po napisaniu dramatycznego listu do Bieruta otrzymała najpierw skromny pokoik, a potem własne nowe mieszkanie we Wrzeszczu (s. 98-99). Nic więc dziwnego, że władze stoczni kreowały ją na modelową robotnicę $\mathrm{z}$ awansu społecznego, a jej uśmiechniętą twarz wykorzystywano na propagandowych zdjęciach i plakatach. W końcu zaczęła też dobrze zarabiać. Sielanka trwała jednak tylko do czasu, gdy miała zdrowie i siłę, aby pracować jako spawaczka. Po przejściu na suwnicę zarabiała już zdecydowanie mniej.

Dużą zasługą autorów jest przywrócenie właściwych proporcji oficjalnemu portretowi Anny Walentynowicz. Przecież tak naprawdę z antykomunistyczną opozycją związała się ona dopiero w 1978 roku, czyli wtedy, gdy dołączyła do Wolnych Związków Zawodowych Wybrzeża. Jej rola w rozpoczęciu strajku sierpniowego w 1980 roku była zaś w gruncie rzeczy nieco przypadkowa, gdyż jej zwolnienie ze stoczni posłużyło za pretekst do zorganizowania planowanego już od pewnego czasu strajku ${ }^{12}$. Trudno oprzeć się wrażeniu, że gdyby kierownictwo zakładu wykazało się większą empatią i pozostawiło ją na stanowisku, to najpewniej prze- pracowałaby spokojnie brakujące jej do emerytury pięć miesięcy i dziś zapewne mało kto by o niej pamiętał. Wszak dzielnych kobiet było w szeregach Solidarności o wiele więcej i z pewnością któraś z nich z powodzeniem zajęłaby miejsce Walentynowicz na związkowym piedestale. Określana przez niektórych patetycznym mianem "Anny Solidarność" weszła do historii równie przypadkowo co Lech Wałęsa i wielu innych działaczy Solidarności ${ }^{13}$.

Wartość poznawcza recenzowanej książki nie kończy się na odkłamaniu niektórych kart z życiorysu Anny Walentynowicz. Jest to również interesująca publikacja o najnowszej historii Polski. Zarówno realia przedwojennego Wołynia, czasy II wojny światowej, jak i okres PRL są w niej ukazane bardzo obrazowo. Książka zawiera też wiele ciekawych informacji, choćby tę, że na początku lat dziewięćdziesiątych próbę napisania biografii Anny Walentynowicz podjął młody dziennikarz Paweł Rabiej. Książka nigdy nie ujrzała światła dziennego, a zamiast niej autor opublikował skandalizującą publikację o Mieczysławie Wachowskim ${ }^{14}$. Dodajmy, że Rabiej w latach 2018-2020 był zastępcą prezydenta Warszawy Rafała Trzaskowskiego (s. 417-424). Bardzo interesująca jest też zamieszczona w książce relacja byłego reportera "Trybuny Ludu" Tadeusza Strumffa, będącego pierwszym dziennikarzem, który zjawił się w strajkującej Stoczni Gdańskiej im. Lenina w sierpniu 1980 roku (s. 247-257).

Nie bardzo natomiast rozumiem, dlaczego autorzy często przeplatają swoją narrację drobiazgowymi opisami zamieszczonych w publikacji fotografii. Czyżby chodziło o próbę pobudzenia wyobraźni czytelników? Przecież każdy sam może ocenić to, co na nich widzi. Zabieg ten wydaje się zbędny i nie wnosi nic do treści książki.

12. Zob. m.in. wypowiedź Bogdana Borusewicza opublikowaną w książce Janiny Jankowskiej Portrety niedokończone. Rozmowy z twórcami "Solidarności" 1980-1981, Warszawa 2003, s. 62-65; por. A. Machcewicz, Bunt. Strajki w Trójmieście. Sierpień 1980, Gdańsk 2015, s. 187-200. Z kolei zdaniem Andrzeja Gwiazdy zwolnienie Walentynowicz z pracy było "jawną prowokacją" SB i miało wręcz na celu wzburzenie stoczniowej załogi (Gwiazdozbiór w "Solidarności". Joanna i Andrzej Gwiazdowie w rozmowie z Remigiuszem Okraską, Łódź 2009, s. 136).

13. Na przypadkowość doboru związkowych kadr przywódczych zwrócił uwagę pierwszy rzecznik prasowy gdańskiego MKS Lech Bądkowski (Głód moralnego przywództwa, wywiad Tadeusza Bolduana z Lechem Bądkowskim, "Czas" 1981, nr 13). 
Pomimo skrupulatnego podejścia do tematu autorom nie udało się też uniknąć pomyłek:

- na s. 18 Generalne Gubernatorstwo kolokwialnie nazywają Generalną Gubernią;

- na s. 111 zaniżają liczbę ofiar Poznańskiego Czerwca 1956 roku (nie 58, a co najmniej 73 osoby zostały wówczas zabite $\left.{ }^{15}\right)$;

- na s. 143 wspominają 0 "miejskiej komisji kontroli partii". W rzeczywistości była to Miejska Komisja Kontroli Partyjnej;

- na s. 160 piszą o "kilku" pochodach z drzwiami i zabitym chłopakiem na ulicach Gdyni 17 grudnia 1970 roku. 0 ile mi wiadomo, odbył się tylko jeden taki pochód i jak dotąd żaden z poważnych badaczy tego faktu nie zakwestionował. Oczywiście ulicami Gdyni przeszło tego dnia kilka innych pochodów, ale już bez drzwi i ciała zabitego chłopca ${ }^{16}$;

- na s. 171 w opisie fotografii z wizyty Gierka w Gdańsku błędnie datują i lokalizują spotkanie I sekretarza KC PZPR z gdańskimi robotnikami. Odbyło się ono 25 stycznia 1971 roku w gmachu Prezydium Wojewódzkiej Rady Narodowej, a nie dzień wcześniej w Stoczni Gdańskiej;

- na s. 178 w opisie fotografii przedstawiającej pierwszomajowy pochód z 1971 roku błędnie lokalizują miejsce wykonania opisywanego zdjęcia. Fotografia ta została wykonana w Szczecinie, a nie w Gdańsku;

- na s. 191 piszą, że premier Piotr Jaroszewicz ogłosił podwyżkę cen żywności w niedzielę 24 czerwca 1976 roku. W rzeczywistości ogłosił ją w czwartek;

- na s. 210 określają Edwina Myszka mianem „założyciela" WZZ Wybrzeża. Był on, co prawda, członkiem Komitetu Założycielskiego, ale trudno nazwać go "założycielem" tej opozycyjnej organizacji ${ }^{17}$;

- I sekretarzem KW PZPR w Katowicach był Andrzej Żabiński, a nie Żabczyński (s. 300);

- "Solidarność" nie mogła liczyć w końcu 1980 roku 9 milionów członków, gdyż w listopadzie 1980 miała ich "zaledwie" 4,4 miliona, a w marcu 1981 - 8 milionów $^{18}$ (s. 301);

- nocą z 12 na 13 grudnia 1981 roku większość członków Komisji Krajowej NSZZ "Solidarność" nocowała w gdańskim Monopolu i sopockim Grand Hotelu, pozostali nocowali we własnych mieszkaniach lub rozjechali się do regionów tuż po zakończeniu obrad. Nie nocowali natomiast w gdańskim Heveliusie $^{19}$ (s. 336).

Biorąc pod uwagę, że recenzowana książka liczy ponad 500 stron, wypada stwierdzić, że wymienione wyżej (skądinąd drobne) potknięcia i nieścisłości nie są zbyt liczne. W niczym też nie zmieniają mojej jednoznacznie pozytywnej oceny książki, którą uważam za rzetelnie przygotowaną i - co równie ważne - dobrze napisaną. $Z$ uwagi na przystępny styl można ją śmiało polecić szerokiemu kręgowi czytelników.

Pewien niedosyt budzi natomiast przedostatni rozdział książki, zatytułowany Przybywa agentów i zdrajców, w którym opisane zostały ostatnie lata życia Anny Walentynowicz. Ma on formę dość suchego kalendarium wydarzeń i sprawia wrażenie napisanego nieco pobieżnie i jakby bez pomysłu na rozwinięcie ciekawszej narracji.

Konkludując, trzeba wyraźnie podkreślić, że choć Dorota Karaś i Marek Sterlingow obalają wiele mitów narosłych wokół postaci słynnej suwnico-

14. P. Rabiej, I. Rosińska, Kim pan jest, panie Wachowski?, Warszawa 1993.

15. Poznański Czerwiec 1956, red. J. Maciejewski, Z. Trojanowiczowa, wyd. 2, Poznań 1990, s. 112-120.

16. Por. P. Brzeziński, R. Chrzanowski, A. Nadarzyńska-Piszczewiat, Zbrodnia bez kary. Grudzień 1970 w Gdyni. Przebieg wydarzeń, represje, walka o prawde, Gdynia 2010, s. 63-69.

17. Por. Wolne Związki Zawodowe Wybrzeża 1978-1980 w relacjach, koncepcja i opieka naukowa I. Hałagida, wstęp P. Brzeziński, oprac. biogramów i relacji A. Kazański, Gdańsk-Warszawa 2018.

18. P. Brzeziński, Zwijanie sztandaru. Komitet Wojewódzki PZPR w Gdańsku w latach 1975-1990, Gdańsk-Warszawa 2019 , s. $312-313$.

19. Idem, Grajcie, jakby nic się nie stało, "Dziennik Bałtycki”, 9.12.2011. 
wej, to nie oceniają jej, nie ferują pochopnych sądów, a jedynie po ludzku starają się ją zrozumieć. Mają zresztą dużo empatii dla swojej bohaterki, co wśród autorów wydawanych współcześnie książek biograficznych wcale nie jest normą. To kolejna zaleta tej publikacji. Na jej uczciwość zwrócił zresztą uwagę syn Anny Walentynowicz, który po lekturze wyznał dziennikarzowi „Dziennika Bałtyckiego": „Muszę panu powiedzieć, że jest to napisane bardzo rzetelnie. Nie ma tu jakichś wkrętów od autorów, dywagacji. Opierali się na dokumentach i na wspomnieniach ludzi, z którymi mama miała do czynienia, i do których oni dotarli"20. Równie ważne jest to, że w przeciwieństwie do niektórych wcześniejszych biografów Anny Walentynowicz Dorota Karaś i Marek Sterlingow nie czynią z niej postaci spiżowej. Wszak życie żadnego człowieka nie jest czarno-białym komiksem dla dzieci, a upiększanie historii bądź rozmyślne ignorowanie faktów niepasujących do przyjętej zawczasu tezy prędzej czy później ośmiesza "poprawiających" historię autorów.

Po lekturze recenzowanej publikacji mogę stwierdzić, że stanowi ona najlepszą znaną mi książkę o Annie Walentynowicz i będzie z pewnością interesującą lekturą dla wszystkich tych czytelników, którzy od dobrej biografii oczekują czegoś więcej niż przesłodzonej, okolicznościowej laurki.

20. Najwyżej grób mojej mamy pozostanie pusty, wywiad Dariusza Szretera z Januszem Walentynowiczem, "Dziennik Bałtycki”, 10.04.2020. 